\title{
PEMANFAATAN $\mathrm{HCl}$ dan $\mathrm{CaCl}_{2}$ SEBAGAI ZAT AKTIVATOR DALAM PENGOLAHAN LIMBAH INDUSTRI TAHU
}

\author{
Surya Hatina ${ }^{1}$, Ria Komala ${ }^{2}$, Randa Wahyudi ${ }^{3}$ \\ ${ }^{123)}$ Program Studi Teknik Kimia Universitas Tamansiswa Palembang \\ Jl. Tamansiswa No.261, 20 Ilir D. I, Ilir Tim. I, Kota Palembang \\ email : surya.hatina@gmail.com
}

\begin{abstract}
ABSTRAK
Penelitian ini bertujuan untuk mengetahui efektivitas kerja karbon aktif dari ampas tebu dengan zat aktivator $\mathrm{HCl}$ dan $\mathrm{CaCl}_{2}$ dalam mengurangi parameter COD dan TSS serta menaikkan parameter DO dan PH pada limbah hasil pengolahan tahu.Kondisi optimum dalam mengurangi parameter COD dan TSS serta menaikkan parameter DO dan PH pada limbah hasil pengolahan tahu adalah waktu sirkulasi 12 jam dengan alat fixed bed reaktor. Hasil penelitian dengan penggunaan zat aktivator $\mathrm{HCl} 0,3 \mathrm{M}$ memiliki kemampuan lebih baik dari pada $\mathrm{CaCl} 0,2 \mathrm{M}$ dalam menurunkan nilai COD dan TSS serta menaikan nilai DO dan PH. Penurunan nilai COD dari123,7 mg/L menjadi41,6 mg/L atau sebesar $66,37 \%$, penurunan nilai TSS dari $335 \mathrm{mg} / \mathrm{L}$ menjadi $103,8 \mathrm{mg} / \mathrm{L}$ atau sebesar $69,1 \%$, kenaikan nilai DO dari 1,86 mg/L menjadi 7,6 mg/L atau sebesar 75,52\%, dan kenaikan nilai $\mathrm{pH}$ dari 3,53 menjadi 4,66 .
\end{abstract}

Kata Kunci : adsorpsi,zat aktivator, limbah cair tahu, karbon aktif

\section{PENDAHULUAN}

Salah satu proses yang sering di pakai di industri adalah proses adsorpsi.Adsorben yang paling potensial adalah karbon aktif sebab memiliki luas permukaan yang tinggi sehingga kemampuan adsorpsinya besar. Penelitian ini merujuk pada pengujian pengolahan limbah zat cair industry kususnya limbah industri tahu.

Limbah cair pabrik tahu memiliki kandungan senyawa organik yang tinggi. Sebagian besar limbah cair yang dihasilkan oleh industri pembuatan tahu adalah cairan kental yang terpisah dari gumpalan tahu yang disebut air dadih (whey). Limbah cair ini sering dibuang secara langsung tanpa pengolahan terlebih dahulu sehingga akan mencemari lingkungan sekitar.

Hasil studi kasus tentang karekteristik air buangan industri tahu di Palembang (Bappeda, 2010), dilaporkan bahwa air buangan industri tahu mengandung BOD, COD, TSS dan DO berturut-turut sebesar 4583, 7050, 4743, 4,228mg/L. Bila dibandingkan dengan data baku mutu limbah cair bagi kegiatan industri menurut Peraturan Menteri Lingkungan Hidup Republik Indonesia No.5 Tahun 2014 tentang Baku Mutu Limbah Cair bagi Kegiatan Industri pengolahan kedelai khususnya industri tahu, kadar maksimum yang dibolehkan untuk BOD, COD, TSS berturut-turut adalah 150, 300 dan 200 mg/L, menurut PP no. 82 tahun 2001 tentang kriteria mutu air, kadar minimum yang dibolehkan untuk DO adalah 6 mg/l ,dan menurut PERGUB SUMSEL no. 8 tahun 2012 tentang baku mutu limbah cair untuk industri, kadar maksimum yang dibolehkan untuk BOD dan TSS berturut-turut adalah 75 dan 50 
mg/l, kadar minimun DO adalah $6 \mathrm{mg} / \mathrm{l}$, sehingga jelas bahwa limbah cair industri tahu telah melampaui standar baku mutu yang dipersyaratkan.

Penelitian pengolahan limbah cair tahu sebelumnya juga telah dilakukan dengan alat fixed bed reaktor biofiltrasi aerobik dengan media kerikil dan cukup mampu untuk menurunkan kadar COD, dan TSS pada limbah cair tahu (Aminah. 2012). Penelitian pembuatan karbon aktif juga telah dilakukan dengan bahan baku ampas tebu dengan $\mathrm{HCl}$ sebagai aktivatornya untuk mengurangi dampak lingkungan dari limbah ampas tebu (Surya Hatina, 2015). Dari penelitian terdahulu tersebut, penelitian ini akan menerapkan teknologi pengolahan limbah cair industri tahu dengan cara fisika dengan menggunakan alat fixed bed reactor dengan media penyaring karbon aktif dari ampas tebu dengan aktivasi kimia $\mathrm{HCl}$ dan $\mathrm{CaCl}_{2}$. Diharapkan pemilihan media karbon aktif ini mampu menggantikan posisi bahan penyerap lainnya dan memberikan suatu alternatif pengolahan limbah cair industri tahu dan dapat mengetahui efektivitas kerja karbon aktif dari ampas tebu dengan zat aktivator $\mathrm{HCl} 0,3 \mathrm{M}$ dan $\mathrm{CaCl}_{2}$ 0,2 $\mathrm{M}$ dalam mengurangi parameter COD dan TSS serta menaikkan parameter DO pada limbah hasil pengolahan tahu.

Permasalahan dalam penelitian ini adalah mendapatkan hasil maksimal dari zat aktivator yang paling efektif antara zat aktivator $\mathrm{HCl} 0,3 \mathrm{M}$ dan $\mathrm{CaCl}_{2} \quad 0,2 \mathrm{M}$ dalam pembuatan karbon aktif dari ampas tebu yang akan digunakan sebagai media adsorpsi pada alat fixed bed reaktor untuk pengolahan limbah cair tahu dalam mengurangi parameter COD dan TSS serta menaikkan parameter DO dan PH pada limbah hasil pengolahan tahu.

Tujuan penelitian untuk mengetahui efektivitas kerja karbon aktif dari ampas tebu dengan zat aktivator $\mathrm{HCl}$ 0,3 $\mathrm{M}$ dan $\mathrm{CaCl}_{2}$ 0,2 $\mathrm{M}$ dalam mengurangi parameter COD dan TSS serta menaikkan parameter DO pada limbah hasil pengolahan tahu.

Penelitian ini dapat memberikan manfaat mendapatkan data parameter yang terkandung dalam limbah cair tahu.,memberikan suatu alternatif pengolahan limbah cair industri tahu, sehingga dapat membantu menanggulangi pencemaran lingkungan.Sebagai sumber ilmu pengetahuan

\section{TINJAUAN PUSTAKA}

Adsorpsi adalah peristiwa pengambilan zat yang berbentuk gas, uap dan cairan oleh permukaan atau antarmuka tanpa penetrasi. Faktor terpenting dalam proses adsorpsi adalah luas permukaan. Suatu molekul pada antarmuka/permukaan mengalami ketidakseimbangan gaya. Akibatnya, molekul-molekul pada permukaan ini mudah sekali menarik molekul lain, sehingga keseimbangan gaya akan tercapai. Dengan teradsorpsinya molekul lain pada permukaan, maka terjadi pengurangan terhadap tegangan permukaan dan adsorpsi akan berlangsung terus sampai energi bebas permukaan mencapai batas minimum. Dari proses adsorpsi ini, dikenal istilah adsorbat untuk zat yang diadsorpsi dan adsorben untuk zat yang mengadsorpsi.

Karbon aktif merupakan adsorben terbaik dalam sistem adsorpsi. Ini karena karbon aktif memiliki luas permukaan yang besar dan daya adsorpsi yang tinggi sehingga pemanfaatannya dapat optimal. Karbon aktif yang baik harus memiliki luas permukaan yang besar sehingga daya adsorpsinya juga besar (Prabowo, 2009). Luas permukaan karbon aktif umumnya berkisar antara 300-3000 $\mathrm{m}^{2} / \mathrm{g}$ dan ini terkait dengan struktur pori pada karbon aktif tersebut.

Karbon aktif adalah material berpori dengan kandungan karbon 87\%-97\% dan sisanya berupa hidrogen, oksigen, sulfur, dan material lain. Karbon aktif merupakan karbon yang telah diaktivasi sehingga terjadi pengembangan struktur pori yang bergantung pada metode aktivasi yang digunakan. Struktur pori menyebabkan ukuran molekul teradsorpsi terbatas, sedangkan bila ukuran partikel tidak maslah, kuantitas bahan yang diserap dibatasi oleh luas permukaan karbon aktif (Austin, 1996).

Karbon aktif memiliki banyak fungsi, misalnya pada proses pengolahan air, karbon aktif berfungsi untuk menghilangkan polutan seperti seng, timbal, kuprum, krom, besi, timbal, dan uap 
amonia (Murti, 2008; Junior dkk, 2009; Prabowo, 2009; Lienden dkk, 2010). Karbon aktif juga berfungsi dalam pemurnian gas seperti dengan cara desulfurisasi dan menyerap gas beracun dan bau busuk. Selain itu, karbon aktif juga berfungsi sebagai tempat penyimpanan gas hydrogen dan gas metana (adsorptive gas storage).

Tabel 1. Syarat Mutu Karbon Aktif (SII No. 0258-88)

\begin{tabular}{|c|l|c|c|}
\hline \multirow{2}{*}{ No. } & \multicolumn{1}{|c|}{ Jenis Uji } & \multicolumn{2}{c|}{ Persyaratan } \\
\cline { 3 - 4 } & \multicolumn{1}{|c|}{$\begin{array}{c}\text { Butiran } \\
\text { Pagian yang hilang pada } \\
\text { pemanasan } 950^{\circ} \mathrm{C}\end{array}$} & Max. 15\% & Max. 25\% \\
\hline 2 & Air & Max. 4,4\% & Max. 15\% \\
\hline 3 & Abu & Max. 2,5\% & Max.10\% \\
\hline 4 & Daya serap terhadap Iodium & Min. 750 ml/g & Min. 750 ml/g \\
\hline
\end{tabular}

Sumber : Pusat Dokumentasi dan Informasi Ilmiah, LIPI 1997

Pembuatan Karbon Aktif,Secara umum, proses pembuatan karbon aktif terdiri dari 3 tahap yaitu

- Dehidrasi,proses penghilangan kandungan air yang didapat dalam bahan baku karbon aktif dengan tujuan untuk menyempurnakan proses karbonisasi dan dilakukan dengan cara menjemur bahan baku di bawah sinar matahari atau memanaskannya dalam oven.

- Karbonisasi,proses pembakaran material organik pada bahan baku. Karbonisasi akan menyebabkan terjadinya dekomposisi material organik bahan baku dan pengeluaran pengotor. Sebagian besar unsur non-karbon akan hilang pada tahap ini. Pelepasan unsur - unsur yang volatil ini akan membuat struktur pori - pori mulai terbentuk / pori - pori mulai terbuka. Seiring karbonisasi, struktur pori awal akan berubah.Karbonisasi dihentikan bila tidak/mengeluarkan asap lagi. Penambahan suhu memang diperlukan untuk mempercepat reaksi pembentukan pori. Namun, pembatasan suhu pun harus dilakukan. Suhu yang terlalu tinggi, seperti diatas $1000^{\circ} \mathrm{C}$ akan mengakibatkan banyak abu yang terbentuk sehingga dapat menutupi pori - pori dan membuat luas permukaan berkurang serta daya adsorpsinya menurun.

- Aktivasi

Proses aktivasi dibedakan menjadi 2 bagian, yaitu:

a. Proses Aktivasi Termal

Proses aktivasi termal umumnya melibatkan gas pengoksidasi seperti oksida oleh udara pada temperatur rendah, uap $\mathrm{CO}_{2}$ atau aliran gas pada temperatur tinggi (Pohan, 1993).

b. Proses Aktivasi Kimia

Proses aktivasi kimia merujuk pada pelibatan bahan-bahan kimia atau reagen pengaktif. Menurut Kirk and Othmer (1940), bahan kimia yang dapat digunakan sebagai pengaktif diantaranya $\mathrm{CaCl}_{2}, \mathrm{Ca}(\mathrm{OH})_{2}, \mathrm{NaCl}, \mathrm{MgCl}_{2}, \mathrm{HNO}_{3}, \mathrm{HCl}, \mathrm{Ca}_{3}\left(\mathrm{PO}_{4}\right)_{2}, \mathrm{H}_{3} \mathrm{PO}_{4}, \mathrm{ZnCl}_{2}$, dan sebagainya. Aktivasi kimia dilakukan dengan mencampur material karbon dengan reagen pengaktif, selanjutnya campuran dikeringkan dan dipanaskan. Hessler (1951) dan Smith (1992) menyatakan bahwa unsur-unsur mineral aktivator masuk diantara plat heksagon dari kristalit dan memisahkan permukaan yang mula-mula tertutup. Dengan demikian, saat pemanasan dilakukan, senyawa kontaminan yang berada dalam pori menjadi lebih mudah terlepas. Hal ini menyebabkan luas permukaan yang aktif bertambah besar dan meningkatkan daya serap karbon aktif. 
Ampas Tebu sebgai Bahan Baku Karbon Aktif, Tebu (Saccharum officinarium) tergolong tanaman perkebunan dan hanya dapat tumbuh didaerah tropis. Hal ini menjadikan pertumbuhan dan perkembangan tebu di Indonesia tergolong baik karena curah hujan dan intensitas sinar matahari yang cukup tinggi. Tebu digunakan sebagai bahan baku untuk memproduksi gula. Proses produksi gula ini menghasilkan limbah atau residue. Limbah merupakan hasil dari suatu proses yang belum atau tidak termanfaatkan (Murti, 2008). Salah satu penggunaan efektif dari limbah agrikultural yang menjadi perhatian pada dekade terakhir adalah sebagai bahan baku dalam pembuatan karbon aktif. Banyak limbah agrikultural yang dipakai sebagai bahan baku pembuatan karbon aktif karena dapat diperbaharui, tersedia dalam jumlah banyak, dan tidak terlalu mahal dari pada material lain untuk dijadikan adsorben (Nunes dkk, 2008). Proses pembuatan gula akan menghasilkan limbah berupa ampas tebu. Ampas tebu ini merupakan hasil samping proses ekstrasi cairan tebu pada indrustri gula. Sebagian besar pemanfaatan ampas tebu ini bernilai ekonomi yang cukup rendah misalnya hanya terbatas untuk pakan ternak atau sebagai bahan bakar boiler di pabrik gula. Pemanfaatan ampas tebu perlu pengembangan teknologi, salah satunya ialah dapat dijadikan bahan baku pembuatan karbon aktif. Selain itu, pemanfaatan ampas tebu ini dapat mengurangi dampak bagi lingkungan yang diakibatkan limbah.

Ampas tebu dapat digunakan sebagai bahan baku pembuatan karbon aktif karena merupakan material yang mengandung lignoselulosa. Lignoselulosa merupakan unsur yang banyak mengandung karbon. lignoselulosa terdiri dari lignin, selulosa, dan hemiselulosa. Material yang mengandung lignin memiliki kandungan karbon sekitar $35 \%-40 \%$, densitas yang rendah sekitar $0,3 \mathrm{~kg} / \mathrm{m}^{3}-0,4 \mathrm{~kg} . \mathrm{m}^{3}$, dan kandungan abu yang sangat sedikit (Manocha, 2003). Zat yang terkandung dalam ampas tebu dalam jumlah besar yaitu selulosa sekitar $37 \%$, lignin sekitar $21 \%$, dan hemiselulosa sekitar $28 \%$ (Bon, 2009).

Tahu merupakan salah satu bahan makanan pokok di negeri ini, yang termasuk dalam makanan 4 (empat) sehat 5 (lima) sempurna. Tahu juga merupakan makanan yang mengandung sangat banyak gizi dan cukup mudah untuk diproduksi

Limbah Industri Tahu dapat berupa limbah padat dan limbah cair.Limbah padat berupa ampas kedelai yang berasal dari proses penyaringan, saat ini limbah ini sudah dijual dan dimanfaatkan untuk pembuatan tempe gembus, makanan ternak, ada juga yang dimanfaatkan untuk pembuatan produk makanan selain tahu. Sedangkan limbah cairberasal dari air kotor bekas perendaman kedelai, air kotor bekas proses penggilingan, air kecutan bekas proses penggumpalan, air kotor bekas pencetakan dan air kotor bekas perendaman tahu jadi.Limbah cair pada industri tahu sudah menjadi permasalahan yang bersifat umum/publik dimana limbah cair kebanyakan dibuang langsung ke sungai, pekarangan rumah, sawah sehingga mencemari sumber air bersih di lingkungan sekitar dan menimbulkan polusi udara (bau menyengat).

Hasil studi kasus tentang karekteristik air buangan industri tahu di Palembang (Bappeda, 2010), dilaporkan bahwa air buangan industri tahu mengandung BOD, COD, TSS dan DO berturutturut sebesar 4583, 7050, 4743, 4,228 mg/L. Bila dibandingkan dengan data baku mutu limbah cair bagi kegiatan industri menurut keputusan Menteri Lingkungan Hidup No.51/MENLH/10/1995 tentang Baku Mutu Limbah Cair bagi Kegiatan Industri, kadar maksimum yang dibolehkan untuk BOD, COD, TSS berturut-turut adalah 50, 100 dan $200 \mathrm{mg} / \mathrm{L}$, menurut PP no. 82 tahun 2001 tentang kriteria mutu air, kadar minimum yang dibolehkan untuk DO adalah $6 \mathrm{mg} / 1$, dan menurut PERGUB SUMSEL no. 16 tahun 2005 tentang baku mutu air sungai, kadar maksimum yang dibolehkan untuk BOD, COD, TSS berturut-turut adalah 2, 10, $50 \mathrm{mg} / \mathrm{l}$ dan kadar minimun DO adalah $6 \mathrm{mg} / \mathrm{l}$, sehingga jelas bahwa limbah cair industri tahu telah melampaui baku mutu yang dipersyaratkan.Pada penelitian ini, limbah cair tahu di dapat dari perajin tahu di Jalan Asia Plaju Palembang.

Parameter Limbah Industri Tahu : 


\section{- Chemical Oxygen Demand (COD)}

COD adalah banyaknya oksigen yang dibutuhkan untuk mengoksidasi secara kimia bahan organik di dalam air. Angka COD merupakan ukuran bagi pencemaran air oleh zat - zat organis yang secara alamiah dapat dioksidasikan melalui proses mikrobiologis, dan mengakibatkan berkurangnya oksigen terlarut di dalam air.

- Total Suspendid Solid (TSS)

TSS yaitu bahan - bahan yang melayang dan tidak larut dalam air. Padatan tersuspensi sangat berhubungan erat dengan tingkat kekeruhan air, semakin tinggi kandungan bahan tersuspensi, maka air akan semakin keruh. TSS menunjukkan besarnya padatan tersuspensi di dalam limbah.

- DO (Dissolved Oxygen) atau Oksigen Terlarut

Di dalam air, oksigen memainkan peranan dalam menguraikan komponen-komponen kimia menjadi komponen yang lebih sederhana.Oksigen memiliki kemampuan untuk beroksida dengan zat pencemar seperti komponen organik sehingga zat pencemar tersebut tidak membahayakan. Oksigen juga diperlukan oleh mikroorganisme, baik yang bersifat aerob serta anaerob, dalam proses metabolisme. Dengan adanya oksigen dalam air, mikroorganisme semakin giat dalam menguraikan kandungan dalam air.

Kandungan oksigen terlarut (DO) menunjukkan cadangan oksigen dalam air sungai tersebut. Kadar oksigen terlarut dalam perairan alami biasanya kurang dari $10 \mathrm{mg} / \mathrm{l}$. Oleh karena itu kadar oksigen terlarut dapat dijadikan ukuran untuk menentukan kualitas air. Penurunan kadar oksigen terlarut dalam perairan merupakan indikasi kuat adanya pencemaran terutama pencemaran bahan organik.

- $\mathrm{pH}$

Nilai $\mathrm{pH}$ air digunakan untuk mengekpresikan kondisi keasaman air limbah. Skala pH berkisar antara $1-14$, kisaran nilai $\mathrm{pH} 1>-7$ termasuk kondisi asam, $\mathrm{pH} 7>-14$ termasuk kondisi basa, dan pH 7 adalah kondisi netral (Siregar, 2005). Air limbah industri tahu sifatnya cenderung asam (BPPT, 1997), pada keadaan asam ini akan terlepas zat - zat yang mudah menguap. Hal ini mengakibatkan limbah cair industri tahu mengeluarkan bau busuk.

Pengolahan Limbah Cair Industri Tahu secara umum dapat digolongkan atas 3 jenis metode pengolahan, yaitu secara fisika, kimia maupun biologis.

- Cara Fisika

Merupakan metode pemisahan sebagian dari beban pencemaran khususnya padatan tersuspensi atau koloid dari limbah cair dengan memanfaatkan gaya - gaya fisika (MetCalf\&Eddy, 2003). Dalam pengolahan limbah cair industri tahu secara fisika, proses yang dapat digunakan antara lain filtrasi dan pengendapan. Filtrasi (penyaringan) menggunakan media penyaring terutama untuk menjernihkan dan memisahkan partikel - partikel kasar dan padatan tersuspensi dari limbah cair.

- Cara Kimia

Merupakan metode penghilangan atau konversi senyawa - senyawa polutan dalam limbah cair dengan penambahan bahan - bahan kimia atau rekasi kimia lainnya (MetCalf \& Eddy, 2003). Beberapa proses yang dapat diterapkan dalam pengolahan limbah cair tahu diantaranya termasuk koagulasi/flokulasi dan netralisasi. Proses netralisasi biasanya diterapkan dengan cara penambahan asam atau basa guna menetralisir ion - ion terlarut dalam limbah cair sehingga memudahkan proses pengolahan selanjutnya.

- Cara Biologi

Cara biologi dapat menurunkan kadar zat organik terlarut dengan memanfaatkan mikriorganisme atau tumbuhan air. Pada dasarnya cara biologi adalah pemutusan molekul kompleks menjadi molekul sederhana. Proses ini sangat peka terhadap faktor suhu, $\mathrm{pH}$, oksigen terlarut dan zat - zat 
inhibitor terutama zat - zat beracun.Mikroorganisme yang digunakan untuk pengolahan limbah adalah bakteri, algae, atau ptotozoa (Ritmann dan McCarty, 2001). Sedangkan tumbuhan air yang mungkin dapat digunakan termasuk gulma air

\section{METODE PENELITIAN}

Blok diagram penelitian seperti pada Gambar 1.

Pembuatan Karbon

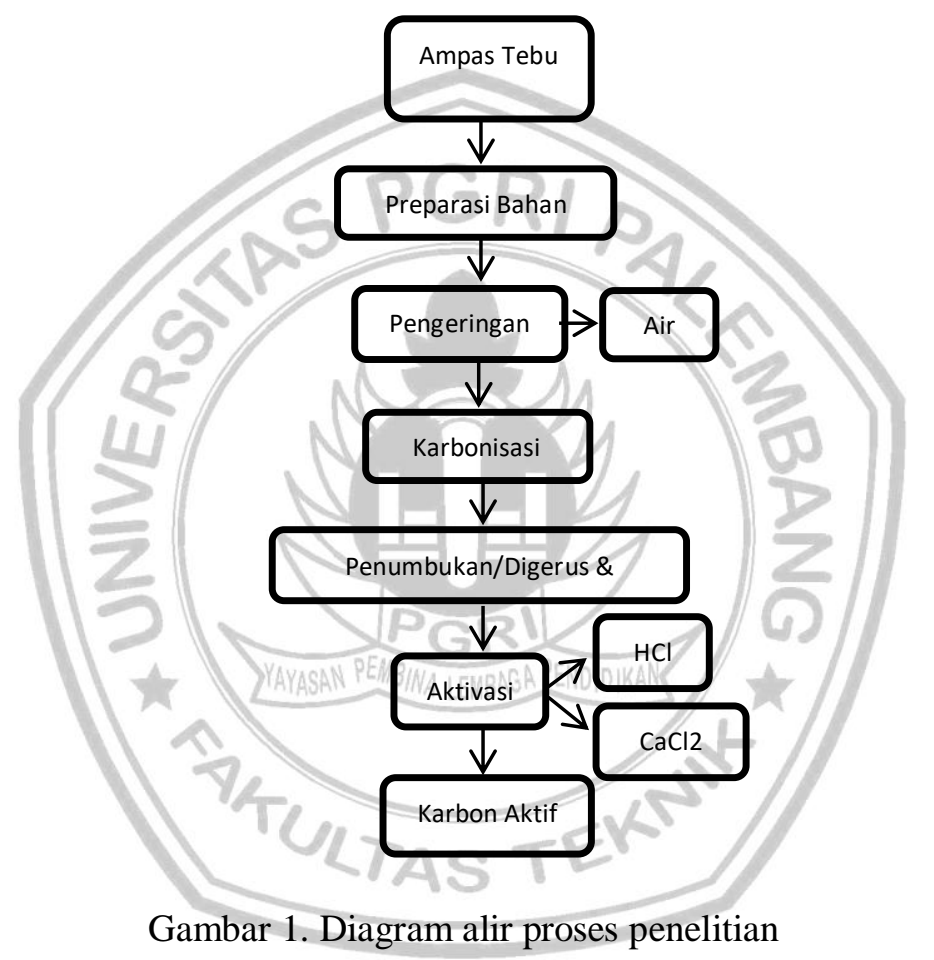

1. Ampas tebu dalam keadaan kering dipotong-potong.

2. Lakukan pembakaran di atas furnace selama 15 menit. Suhu pembakarannya ditentukan $500^{\circ} \mathrm{C}$.

3. Arang yang dihasilkan tersebut digiling di kurs porselin.

4. Lakukan pengayakan dengan ukuran 250 mesh.

Pengaktifan Karbon

1. Arang direndam di dalam larutan aktivator yang berbeda masing - masing dengan waktu aktivasi selama 1 jam.

2. Dari langkah di atas didapat sampel pasta arang. Sample kemudian disaring dengan kertas saring,dan di cuci dengan aquadest hingga $\mathrm{pH} 7$.

3. Keringkan dalam oven pada suhu $150^{\circ} \mathrm{C}$ selama 2 jam.

4. Di dapatkan 2 macam sampel dengan larutan aktivator yang berbeda.

\section{HASIL DAN PEMBAHASAN}

\section{Hasil}

Data Hasil Analisa COD, TSS, DO, dan pH limbah cair tahu pada kondisi awal dan setelah penelitian disajikan masing-masing pada Tabel 2 dan Tabel 3. 
Tabel 2. Analisa awal limbah tahu

\begin{tabular}{|c|c|}
\hline Parameter & Nilai \\
\hline COD $(\mathrm{mg} / \mathrm{L})$ & 123,7 \\
\hline TSS $(\mathrm{mg} / \mathrm{L})$ & 335 \\
\hline DO $(\mathrm{mg} / \mathrm{L})$ & 1,86 \\
\hline $\mathrm{pH}$ & 3,53 \\
\hline
\end{tabular}

Tabel 3.Analisa limbah tahu setelah penelitian

\begin{tabular}{|c|c|c|c|c|c|}
\hline \multirow{2}{*}{$\begin{array}{c}\text { Zat } \\
\text { Aktivator }\end{array}$} & \multirow{2}{*}{$\begin{array}{c}\text { Waktu } \\
\text { Sirkulasi } \\
\quad \text { (jam) }\end{array}$} & \multicolumn{4}{|c|}{ Analisa } \\
\hline & & $\begin{array}{c}\text { COD } \\
(\mathrm{mg} / \mathrm{L})\end{array}$ & $\begin{array}{c}\text { TSS } \\
(\mathrm{mg} / \mathrm{L})\end{array}$ & $\begin{array}{c}\text { DO } \\
(\mathrm{mg} / \mathrm{L})\end{array}$ & pH \\
\hline \multirow{5}{*}{$\begin{array}{c}\mathrm{HCl} \\
0,3 \mathrm{M}\end{array}$} & 4 & 118,4 & 182 & 5,33 & 4,07 \\
\hline & 6 & 86,4 & 167,66 & 6,67 & 4,09 \\
\hline & 8 & 60,8 & 155,03 & 6,8 & 4,20 \\
\hline & 10 & 53,33 & 113,33 & 7,2 & 4,25 \\
\hline & 12 & 41,6 & 103,8 & 7,6 & 4,66 \\
\hline \multirow{5}{*}{$\begin{array}{l}\mathrm{CaCl}_{2} \\
0,2 \mathrm{M}\end{array}$} & 4 & 106,66 & 189 & 2,13 & 4,99 \\
\hline & 6 & 99,2 & 162 & 2,267 & 5,15 \\
\hline & 41 & 70,4 & 156,18 & 2,4 & 5,19 \\
\hline & $\infty$ & 54,4 & 169,66 & 3,13 & 5,50 \\
\hline & 2 & 48 & 158,66 & 3,46 & 5,43 \\
\hline
\end{tabular}

\section{Pembahasan Hasil Penelitian}

1. Analisa Pengaruh Zat Aktivator dan Waktu Sirkulasi terhadapPenurunan COD

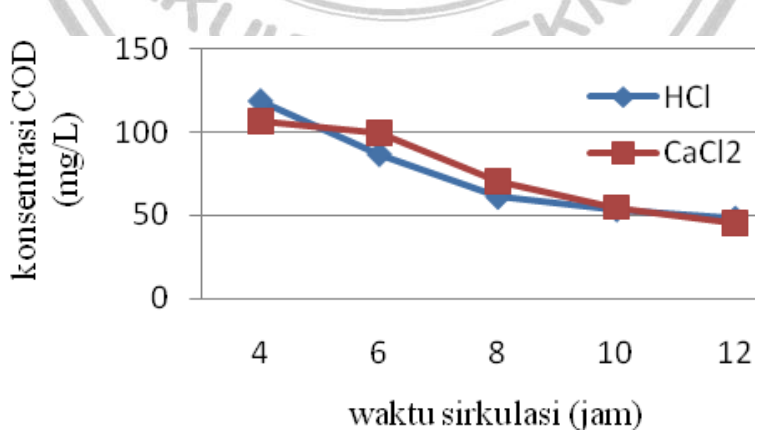

Gambar 2. Pengaruh Zat Aktivator dan Waktu SirkulasiterhadapPenurunan COD

Untuk menyatakan kualitas air dibutuhkan beberapa parameter yang terkait. Salah satu diantaranya adalah Chemical Oxygen Demand (COD) yang didefinisikan sebagai jumlah oksigen yang dibutuhkan untuk mengoksidasi zat - zat organik yang ada dalam sampel air, dimana pengoksidasi kuat seperti kalium kromat $\left(\mathrm{K}_{2} \mathrm{Cr}_{2} \mathrm{O}_{7}\right)$ atau kalium permanganat $\left(\mathrm{KmnO}_{4}\right)$ digunakan sebagai sumber oksigen.

Angka COD merupakan ukuran bagi pencemaran air oleh zat - zat organik secara alamiah dapat dioksidasikan melalui proses mikrobiologis, dan mengakibatkan berkurangnya oksigen terlarut didalam air.

Hasil analisa nilai COD merujuk pada variasi zat aktivator pada karbon aktif sebagai media adsorpsi dan waktu sirkulasi pada alat fix bed reaktor terhadap konsentrasi COD. Dari proses 
pengolahan limbah cair tahu pada alat fixed bed reactor, diketahui bahwa nilai COD menurun seiring dengan lamanya sirkulasi pada alat fixed bed reactor.

Penurunan maksimal terjadi pada sirkulasi 12 jam dan media karbon aktif aktivator $\mathrm{HCl}$ yaitu sebesar 41,6 mg/L pada proses ini dapat menurunkan nilai COD mencapai 66,37\% dari nilai awal COD $123,7 \mathrm{mg} / \mathrm{L}$. Dari nilai ini menunjukkan penurunan nilai yang cukup tinggi dan bisa dikatakan proses ini mampu menurunkan nilai COD dari limbah cair tahu, sehingga pengolahan dengan menggunakan proses ini dapat dikatakan proses yang baik untuk pengolahan limbah cair tahu.

\section{Analisa Pengaruh Zat Aktivator dan Waktu Sirkulasi terhadap Penurunan TSS}

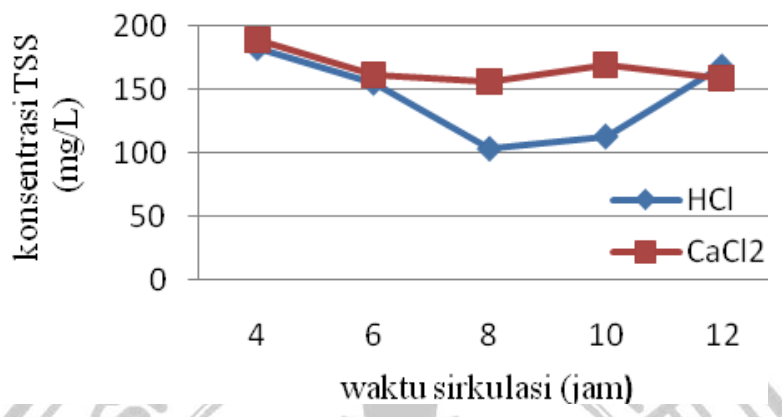

Gambar 3. Pengaruh Zat Aktivator dan Waktu Sirkulasi terhadapPenurunan TSS

Terdapatnya jumlah TSS dalam jumlah yang berlebihan merupakan salah satu faktor yang menyebabkan kekeruhan dalam limbah cair tahu, padatan ini tidak terlarut dan tidak dapat mengendap secara langsung, terdiri dari partikel - partikel yang ukuran maupun beratnya lebih kecil dari sedimen. Konsentrasi TSS yang cukup tinggi pada air limbah tahu ini disebabkan oleh tingginya kadar bahan organik yang terdapat dalam air limbah tahu.

Hasil analisa nilai TSS merujuk pada variasi zat aktivator pada karbon aktif sebagai media adsorpsi dan waktu sirkulasi pada alat fix bed reaktor terhadap konsentrasi TSS. Diketahui bahwa nilai TSS menurun seiring dengan lamanya sirkulasi pada alat fixed bed reactor walaupun penurunannya tidak signifikan. Hal ini dikarenakan masih tingginya kadar bahan organik yang terdapat pada limbah cair tahu yang belum terserap oleh karbon aktif.

Penurunan maksimaldari analisa nilai TSS pada proses pengolahan limbah cair tahu ditunjukkan pada sirkulasi 12 jam pada aktivator $\mathrm{HCl} 0,3 \mathrm{M}$ yaitu sebesar 103,8 $\mathrm{mg} / \mathrm{L}$ pada proses ini dapat menurunkan nilai TSS mencapai $69,1 \%$ dari nilai awal TSS sebesar $335 \mathrm{mg} / \mathrm{L}$. Dari nilai ini bisa dikatakan proses ini mampu menurunkan nilai TSS dari limbah cair tahu, sehingga pengolahan dengan menggunakan proses ini dapat dikatakan proses yang baik untuk pengolahan limbah cair tahu

3. Analisa Pengaruh Zat Aktivator dan Waktu Sirkulasi terhadap kenaikan DO

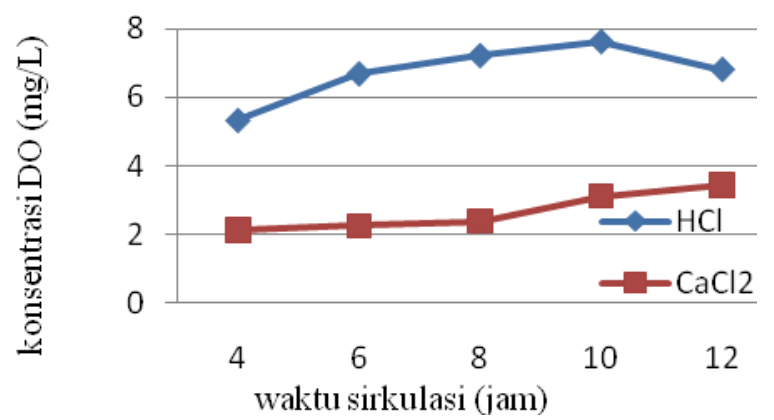

Gambar 4. Pengaruh Zat Aktivator dan Waktu Sirkulasi terhadapkenaikan nilai DO 
Kandungan oksigen terlarut (DO) menunjukkan cadangan oksigen dalam air sungai tersebut. Dilihat dari jumlahnya, oksigen terlarut adalah satu jenis gas terlarut dalam air pada urutan kedua setelah nitrogen. Namun jika dilihat kepentingannya bagi kehidupan, oksigen menempati urutan paling atas.

Oksigen memainkan peranan dalam menguraikan komponen-komponen kimia menjadi komponen yang lebih sederhana.Oksigen memiliki kemampuan untuk beroksida dengan zat pencemar seperti komponen organik sehingga zat pencemar tersebut tidak membahayakan. Oksigen juga diperlukan oleh mikroorganisme, baik yang bersifat aerob serta anaerob, dalam proses metabolisme. Dengan adanya oksigen dalam air, mikroorganisme semakin giat dalam menguraikan kandungan dalam air. Oleh karena itu kadar oksigen terlarut dapat dijadikan ukuran untuk menentukan kualitas air. Penurunan kadar oksigen terlarut dalam perairan merupakan indikasi kuat adanya pencemaran terutama pencemaran bahan organik.

Analisa DO pada penelitian ini dilakukan dengan metode Winkler yaitu dengan melakukan titrasi. Hasil analisa nilai DO merujuk pada variasi zat aktivator pada karbon aktif sebagai media adsorpsi dan waktu sirkulasi pada alat fix bed reaktor terhadap konsentrasi DO. Dari proses pengolahan limbah cair tahu pada alat fixed bed reactor ini, diketahui bahwa nilai DOnaik seiring dengan lamanya sirkulasi pada alat fixed bed reactor baik menggunakan media karbon aktif aktivator $\mathrm{HCl}$ maupun $\mathrm{CaCl}_{2}$.

Hasil terbaik dari analisa nilai DO pada proses pengolahan limbah cair tahu ditunjukkan pada sirkulasi 12 jam dan media karbon aktif Aktivator HCL 0,3 M yaitu sebesar 7,6 mg/L pada proses ini dapat menaikkan nilai DO hingga mencapai 75,52 \% dari nilai awal DO sebesar 1,86 mg/L.Dari nilai ini menunjukkan kenaikkan nilai yang cukup tinggi dan bisa dikatakan proses ini mampu menaikkan nilai DO dari limbah cair tahu untuk karbon aktif dengan aktivator $\mathrm{HCl}$ 0,3 $\mathrm{M}$. Hal ini dikarenakan lama waktu sirkulasi pada alat fixed bed reactor sehinggaterjadi banyak kontak antara permukaan air dengan udara yang menyebabkan air tersebut kaya akan oksigen kembali yang sebelumnya terpakai oleh mikroorganisme dalam mengurai zat di air limbah tersebut.

\section{Analisa Pengaruh Zat Aktivator dan Waktu Sirkulasi terhadap Peningkatan Nilai pH}

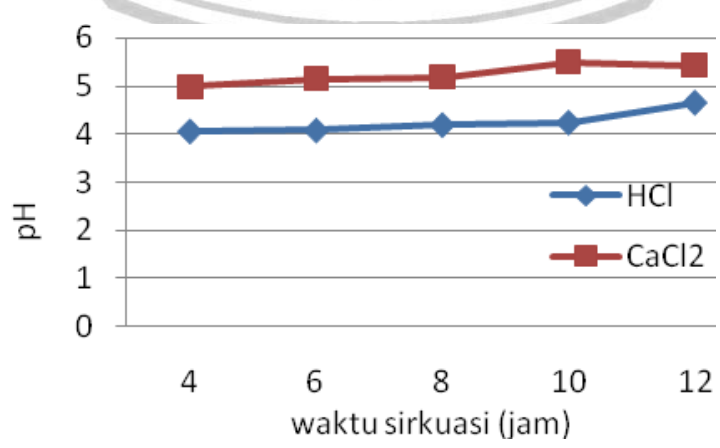

Gambar 5. Pengaruh Zat Aktivator dan Waktu Sirkulasi terhadap Peningkatan Nilai pH

Berdasarkan standar baku mutu limbah tahu, pH limbah cair tahu harus berada pada kisaran 6 - 9. Nilai keasaman pada limbah cair tahu sebelum penyaringan dengan karbon aktif adalah 3,53. Rendahnya nilai keasaman menunjukkan bahwa telah terjadi aktivitas mikroba yang dapat menguraikan bahan - bahan organik menjadi asam.

Berdasarkan hasil yang diperoleh, penyaringan limbah cair tahu dengan media karbon aktif dari ampas tebu mampu meningkatkan nilai $\mathrm{pH}$ pada sirkulasi 12 jam dengan aktivator $\mathrm{CaCl}_{2}$ sebesar 5,43 pada proses ini dapat menaikan $\mathrm{pH}$ mencapai 34,99 \% dari nilai awal $\mathrm{pH}$ sebesar 3,53. Berdasarkan hasil penelitian menunjukkan bahwa penambahan karbon aktif berpengaruh terhadap 
keasaman limbah tahu. Secara umum, karbon aktif dari ampas tebu dengan aktivator $\mathrm{HCl}$ dan $\mathrm{CaCl}_{2}$ ini mampu meningkatkan nilai $\mathrm{pH}$ limbah cair tahu, namun belum mencapai standar nilai $\mathrm{pH}$ baku mutu limbah yaitu pada kisaran $6-9$. Hal ini dipengaruhi oleh luas permukaan karbon aktif yang cukup besar sehingga tidak mampu menyerap dengan optimal.

5.Perbandingan Hasil Percobaan dengan berbagai Peraturan.

Untuk melihat sejauh mana keberhasilan penelitian, maka data hasil penelitian ini diregulasikan dengan berbagai peraturan baku mutu air dan baku mutu limbah cair kegiatan industri, baik lingkup nasional maupun daerah. Perbandingan data tersebut dapat disampaikan pada Tabel berikut ini.

Tabel 4. Perbandingan Hasil Penelitian dengan Ketetapan Peraturan

\begin{tabular}{|c|c|c|c|}
\hline \multirow{5}{*}{ Parameter } & PP NO. 82 & \multicolumn{2}{|c|}{ Hasil } \\
& TH 2001 & \multicolumn{2}{|c|}{ Penelitian } \\
\cline { 3 - 4 } & KUALITAS AIR DAN & HCl & $\mathbf{C a C l}_{\mathbf{2}}$ \\
& PENGENDALIAN & $\mathbf{0 , 3} \mathbf{M}$ & $\mathbf{0 , 2} \mathbf{~ M}$ \\
& PENCEMARAN AIR & Sirkulasi & Sirkulasi \\
& & $\mathbf{1 2}$ jam & $\mathbf{1 2 j a m}$ \\
\hline $\mathrm{COD}(\mathrm{mg} / \mathrm{L})$ & 100 & 41,6 & 48 \\
\hline $\mathrm{TSS}(\mathrm{mg} / \mathrm{L})$ & 200 & 103,8 & 158,66 \\
\hline $\mathrm{DO}(\mathrm{mg} / \mathrm{L})$ & 6 & 7,6 & 3,46 \\
\hline $\mathrm{pH}$ & $6-9$ & 4,66 & 5,43 \\
\hline
\end{tabular}

Pada tabel diatas terlihat bahwa, konsentrasi parameter COD, TSS, DO setelah dilakukan perlakuan dengan pengolahan menggunakan karbon aktif sebagai media adsorpsi di alat fixed bed reaktor ini memberikan hasil yang cukup baik dengan kedua aktivator yaitu $\mathrm{HCl} 0,3 \mathrm{M}$ dan $\mathrm{CaCl}_{2} 0,2$ M. Namun aktivator $\mathrm{HCl} \mathrm{0,3} \mathrm{M} \mathrm{memberikan} \mathrm{hasil} \mathrm{yang} \mathrm{lebih} \mathrm{efektif} \mathrm{dari} \mathrm{pada} \mathrm{aktivator} \mathrm{CaCl}_{2}$. Hal ini dikarenakan karbon yang setelah diaktivasi dengan $\mathrm{HCl}$ 0,3 $\mathrm{M}$ menghasilkan luas permukaan yang lebih baik dari pada karbon yang diaktivasi dengan $\mathrm{CaCl}_{2}$.

Untuk parameter $\mathrm{pH}$ dari hasil penelitian menunjukkan bahwa penambahan karbon aktif berpengaruh terhadap keasaman limbah tahu. Secara umum, karbon aktif dari ampas tebu dengan aktivator $\mathrm{HCl}$ dan $\mathrm{CaCl}_{2}$ ini mampu meningkatkan nilai $\mathrm{pH}$ limbah cair tahu, namun belum mencapai standar nilai $\mathrm{pH}$ baku mutu limbah.

\section{KESIMPULAN}

Adapun kesimpulan yang dapat diambil dari penelitian ini antara lain:

1. Media karbon aktif dengan aktivator $\mathrm{HCl} 0,3 \mathrm{M}$ dan sirkulasi alat fixed bed reactor selama 12 jam memiliki kemampuan yang paling baik dan efektif menurunkan parameter COD dan TSS serta menaikkan parameter DO dan $\mathrm{pH}$ pada limbah hasil pengolahan tahu yaitu menurunkan nilai COD dari123,7 mg/L menjadi41,6 mg/L atau sebesar 66,37 \%, menurunkan nilai TSS dari 335 $\mathrm{mg} / \mathrm{L}$ menjadi $103,8 \mathrm{mg} / \mathrm{L}$ atau sebesar $69,1 \%$, menaikkan nilai DO dari 1,86 mg/L menjadi 7,6 $\mathrm{mg} / \mathrm{L}$ atau sebesar 75,52 \%, dan menaikkan nilai $\mathrm{pH}$ dari 3,53 menjadi 4,66.

2. Dengan melihat hasil penelitian yang telah dilakukan, karbon aktif dari ampas tebu memilki kemampuan meningkatkan kualitas limbah cair tahu yaitu menurunkan parameter COD dan TSS serta menaikkan parameter DO dan PH. 


\section{SARAN}

1. Untuk penelitian selanjutnya, hal yang perlu diperhatikan adalah dalam pembuatan karbon aktif menggunakan bahan yang lain dan jenis zat aktivator yang dapat memberikan hasil yang lebih baik namun lebih ekonomis.

2. Perlu dilakukan penelitian lebih lanjut mengenai parameter lain yang berpengaruh terhadap efisiensi adsoprsi.

3. Perlunya penambahan bahan lain pada limbah cair tahu sebelum dilakukan pengolahan atau penambahan alat penyaringan yang lain untuk menetralkan $\mathrm{pH}$ limbah cair tahu.

\section{DAFTAR PUSTAKA}

Aminah, Kun. 2012. Skripsi : Pengolahan Limbah

Cair Industri Tahu Pada Alat Fixed Bed Reaktor Biofiltrasi Aerobik. Palembang: Jurusan Teknik Kimia Universitas Muhammadiyah Palembang

Animous.TSS dan TDS.i

(www.scribd.com/doc/96260432/Laporan-Praktikum-Kimia-TSS-DAN-TDS) diakses pada 29 Maret 2014

Aqly. 2009. BOD dan COD. (http://www.scribd.com/doc/98953302/BOD-DAN-COD)

Austin, G.T. 1996. Industri Proses Kimia.JakartaErlangga.

Bappeda. 2010. Karakteristik Air Buangan Industri Tahu di Palembang.

Bon, E. P. S. 2009. Ethanol Production via Enzymatic Hydrolysisi of Sugarcane Bagase and Straw. Science an dTechnology. Brazil

BPPT. 2007. Derajat Keasaman (pH) pada Limbah Cair Tahu Sebelum Diolah

Departemen Perindustrian dan Perdagangan. 2003.

Syarat Mutu dan Uji Arang Aktif SII No. 0258-88. Palembang: Balai Perindustrian dan PerdaganganPohan, H. G. 1993. Prospek Penggunaan Karbon Aktif dalam Industri. Bogor: Warta IHP.

Junior, O. K., Gurgel, L. V. A., et al. 2009.

Adsorption of $\mathrm{Cu}(\mathrm{II}), \mathrm{Cd}(\mathrm{II})$, and $\mathrm{Pb}(\mathrm{II})$ from Aqueos Single Metal Solution by Mercerized Cellulose and Mercerized Sugarcane Bagasse Chemically Modified with EDTA Dianhydride (EDTAD). Carbohydrate Polymers77(3) : 643-650

Lienden, C., Shan. L., Rao, S., Ranieri, E., Young,

T.M. 2010.Metals Removal from Stormwater by Commercial and Non-Commercial Granular Activated Carbons. Water Environtment Research 82(6) : 351-356

Lisnasari, S.F., 1995. Pemanfaatan Gulma Air

(Aquatic Weeds) Sebagai Upaya Pengolahan Limbah Cair Industri Pembuatan Tahu. Thesis Master. Program Pasca Sarjana USU Medan. 
MetCalf \& Eddy, 2003, Wastewater Engineering : Treatment, Disposal and Reuse, 4th ed., McGraw Hill Book Co., New York.

Manocha, S.M. 2003. Porous Carbons. Sadhana 28 : 335-348

Murti, S. 2008. Skripsi : Pembuatan Karbon Aktifdari Tongkol Jagung untuk Adsorpsi Molekul Amonia dan Ion Krom. Depok : Universitas Indonesia

Nunes, P.M.C. and Mota, J.P.B., 2008, Adsorption of natural gas and biogas components on activated carbon, Separation and Purification Technology, 62:281-296

Peraturan Menteri Lingkungan Hidup Republik Indonesia Nomor 5 Tahun 2014 Tentang Baku Mutu Air Limbah

PERGUB SUMSEL no. 16 tahun 2012 tentang tentang Baku Mutu Limbah Cair Bagi Kegiatan Industri, Hotel, Rumah Sakit, Domestik dan Pertambangan Batubara

PERGUB SUMSEL no. 16 tahun 2005 tentang baku mutu air sungai

Pohan, H. G. 1993. Prospek Penggunaan Karbon Aktif Dalam Industri. Warta IHP. Bogor

Prabowo, A. L. 2009. Skripsi : Pembuatan Karbon Aktif dari Tongkol Jagung serta Aplikasinya untuk Adsorpsi $\mathrm{Cu}, \mathrm{Pb}$, dan Amonia. Depok : Universitas Indonesia

Rittman dan McCarty. 2014. Kelemahan Pengolahan Limbah Cair Tahu dengan Metode Biofiltrasi.

Shofa. 2013. Skripsi :Pembuatan Karbon Aktif Berbahan Baku Ampas Tebu Dengan Aktivasi Kalium Hidroksida. Depok: Jurusan Teknik Kimia Universitas Indonesia

Siregar, S.A., 2005, "Instalasi Pengolahan Air Limbah", Kanisius, Yogyakarta.

Surya Hatina, 2015. Pemanfaatan Limbah Ampas Tebu Dengan Menggunakan HCl Sebagai Aktivator Untuk Mengurangi Dampak Lingkungan Dari Limbah Industri Tahu. Kinetika. Vol $6: 35-41$ 